\title{
Martabat Tembung Wali of Sunan Gunung Jati: As the value of religious humanism for the people of Cirebon
}

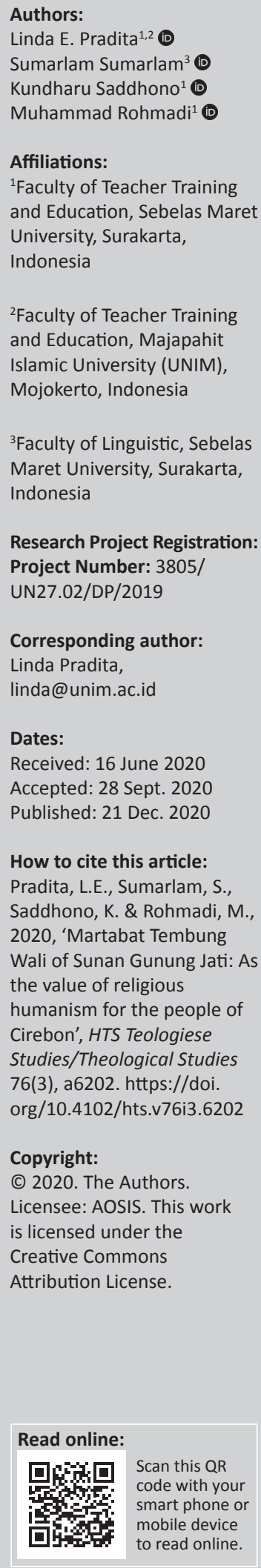

${ }^{3}$ Faculty of Linguistic, Sebelas Maret University, Surakarta, Indonesia

Research Project Registration: Project Number: 3805/ UN27.02/DP/2019

\section{Corresponding author:} Linda Pradita,

linda@unim.ac.id

Dates:

Received: 16 June 2020 Accepted: 28 Sept. 2020 Published: 21 Dec. 2020

How to cite this article: Pradita, L.E., Sumarlam, S., Saddhono, K. \& Rohmadi, M., 2020, 'Martabat Tembung Wali of Sunan Gunung Jati: As the value of religious humanism for the people of Cirebon', HTS Teologiese Studies/Theological Studies 76(3), a6202. https://doi. org/10.4102/hts.v76i3.6202

\section{Copyright:}

(c) 2020. The Authors.

Licensee: AOSIS. This work is licensed under the Creative Commons Attribution License.

\section{Read online:}

Scan this QR
code with your
smart phone or
mobile device
to read online.

This study discusses the teachings of Sunan Gunung Jati as the value of religious humanism in education and history for the people of Cirebon. The teachings of Sunan Gunung Jati are still tightly grasped by the people of Cirebon from ancient times to the present, namely martabat tembung wali because they contain moral teachings and noble cultural values. The teachings of Sunan Gunung Jati have the concept of religious humanism as a form of history. The concept of religious humanism has implications for the educational process, with an orientation to developing human aspects. The purpose of this study is to explore the values of life reflected in the teachings of Sunan Gunung Jati's life as the value of religious humanism in education and history for the people of Cirebon. This research uses an anthropolinguistic theoretical framework to examine the value of religious humanism in education and history for the people of Cirebon. This study uses a qualitative research paradigm. The results showed that the teachings of Sunan Gunung Jati contained the value of life in social rules. Sunan Gunung Jati has relevance to the process of human development. Humans have a personal side that continues to grow in line with the social side. Human development is also surrounded by spiritual components as a form of emotional intelligence.

Contribution: This article contributes to the objective of HTS Teologiese Studies/Theological Studies to investigate the history of religions, as well as phenomenology, psychology, philosophy and sociology of religions.

Keywords: education; local wisdom; petatah-petitih; religious humanism; values.

\section{Introduction}

Education has an important role in developing a better life, becoming a moral and ethical foundation in the process of empowering the nations identity. Education which has been developing so far emphasizes more on mastering science and technology that is not accompanied by a strong basis for the development of human characters who have a noble conscience. Mastery is more prominent than the developing values and attitudes to build moral human beings. Education is essentially an effort to help students develop normatively, better in the intellectual, moral and psychological dimensions, and aims to prepare students to enter society and culture that is constantly changing. Therefore, education should be able to pay attention to all the development of students as a whole human being.

Education is a strategic medium in cultural preservation. Education is directed at helping to change the cultural orientation of individuals and their communities. Education has the aim of preparing a society that is democratic, religious, and has the ability to understand, practice and develop cultural values and maintain national unity and integrity. Based on the importance of education, the essence of education is a process of humanisation. Humanisation has implications for the educational process, with an orientation to develop human aspects of humanity.

Indonesia is a multicultural and multi-ethnic country that has much cultural diversity, consisting of various ethnic groups that are different and have a long history so that many cultural results are feasible to be made into local wisdom. Local wisdom is a view of life and science and various life strategies in the form of activities carried out by local communities in answering various problems in meeting their needs (Fajarini 2014:123-124). In general, the values of politeness and decency contained in local wisdom are taught from generation to generation through oral media in the form of expressions. Each region has a different local wisdom according to the way of life and thinking. 
Throughout history in the archipelago, there are many styles of culture that interact with each other and develop according to life at that time. This was found with the many ancient artefacts and documents that provide information about cultural wealth as the local wisdom of each region. As we know that Indonesia experienced various cultural changes, starting with an animist-dynamism culture, Hinduism, Buddhism, Islam, colonialism and a new culture (acculturation and assimilation), this enriches culture as local wisdom in each region. For example, during the period of Islamisation in Java, the Islamic preacher known as Walisongo combined elements of local culture with Islam. In addition to facilitating the spread of Islam, this is performed to preserve the local wisdom.

During the Islamisation of the archipelago, one of the famous guardians was Sunan Gunung Jati. Sunan Gunung Jati uses noble teachings and local traditions to spread islam. Sunan Gunung Jati does not just leave physical buildings and traditions. His teachings are still well known today. Sunan Gunung Jati left a number of experts or advice and good life guidelines for the social community in Cirebon. In the tomb complex of Sunan Gunung Jati, there are many writings that are still preserved by the residents. The history of Sunan Gunung Jati has various dimensions of viewpoint both in local and national history. As a local history, Sunan Gunung Jati is seen from its territory, namely, in the western part of Java, especially Cirebon. As a national history, Sunan Gunung Jati is seen as one of the important members of the Islamisation process.

\section{Theoretical overview: Education of religious humanism}

From the philosophical point of view, humanism is defined as a notion that upholds the values and dignity of humans so that humans occupy very high, central positions and are important both in philosophical and practical terms in daily life (Abidin 2001:39). The idea of humanism that is based on religion requires that religious people have attention in creating a just moral social order. In Islam, the view of humanism can be explored by the meaning of religion on human values (Endar 2008:181). In the Indonesian context, what is meant by religious humanism is a religious concept that places humans as human beings based on sacred values from religious teaching. There is a synergy and integration between the view of humans as creatures with constantly developing competences and how this development do not conflict with the teachings of religion which become the identity of the Indonesian nation (Nurkholis 2010:8). From the given explanation, humanism is a school of philosophy that places humans as important subjects by giving them the freedom to be able to develop all their abilities and potential, recalling their existence, position and responsibility in their lives. In this process, the existence of religion is important to reflect because religion also saves ideals. The idea of humanism that is based on religion actually requires that religious people have attention in creating a moral and just social order.
When associated with the world of education, religious humanism in education refers to the element of 'humanising humans' in education, whilst at the same time animating it with the noble values of religion. So, all educational activities are inspired by the enthusiasm to develop all human potential in order to become a perfect human being and live out religious values. Religious humanist education accommodates ideas to develop all human potential whilst guiding them according to religious values. In Indonesia, the religious values in question are all religions adopted by the Indonesian nation. Whilst in the Islamic world, religious humanist education is an education based on and inspired by Islamic teachings, the implementation of education must be based on the development of human potential. This is in line with the Islamic view that humans are educated intelligent beings. Mas'ud (2003: 185) argued argues that humanism is religious in education means the process of developing all human competencies as social creatures and religious beings and religious beings whilst at the same time guiding them according to religious values. While in the Islamic world, religious humanist education based on islamic teachings

Value is essential that attaches to something that is very meaningful to human life. Value is attached to perception, especially about goodness as a social human being in social life. Value is something abstract, ideal, not a concrete object, not a fact, and not only a matter of right and wrong that requires empirical proof but a social appreciation that is desired, liked and disliked (Isna 2001:98). Values are firmly rooted in humanitarian principles in the order of social life.

Values in history are values contained in history. Historical value is all events or events that have occurred in the past in peoples lives which are considered important or valuable for human. History has outside and inside. The outside is all things related to human actions (events) while the inside is all things related to the point of view of human thought. Historical values can be interpreted as the essence of human thoughts and actions because history is nothing but a social process (Carr 2014:71). Thus, the historical value is the values obtained from studying human activities in the past through their relics (thought and culture).

\section{Methodology}

This research uses qualitative research methods to help researchers gain an in-depth understanding of Sunan Gunung Jati's heritage as the value of religious humanism and history for the people of Cirebon. The use of this method relates to the nature of the research topic, field of study and available data sources. Moleong (2007:3) asserted that qualitative research is a research procedure that produces descriptive data in the form of written and oral words from people and observed behaviour. This research can be categorised as a qualitative research paradigm procedure because it depends on the interpretation of the researcher. The analysis technique uses interactive data analysis 
techniques that involve three components, namely, data reduction, data presentation and data verification (Milles \& Huberman 2007:20). The data validation technique uses triangulation of sources, methods and theories (Sutopo 2006:92).

\section{Results and discussion History of Sunan Gunung Jati}

At the age of 20, Syarif Hidayatullah was qualified as a teacher of Islamic religion because he had studied Islam in Mecca and Medina. On his way to Cirebon, he stopped at Pasai and lived with Maulana Iskak. When arriving at the port of Muara Djati (Cirebon), he continued to the village of Sembung-Pasambangan near Giri Amparan Djati. There Sunan Gunung Jati taught Islamic religion to replace the deceased Sheikh Datuk Kahfi. Slowly Sunan Gunung Jati adjusted to the local people who considered him a foreigner from Arabia. Sunan Gunung Jati was named Sheikh Maulana Djati or Sheikh Djati. Then, he went to Banten to teach Islam. After returning from Banten, he was given the title by his uncle to become the head of the Nagari and was named Susuhan Djati or Sunan Djati or Sunan Caruban. in history Caruban delevops into a sultanate with the name Sultanate of Cirebon.

In Cirebon, the activities of Sunan Gunung Jati who appeared as the head of state and one of Walisanga prioritised the development of Islamic religion through da'wah, one of which was to provide religious worship facilities by spearheading the construction of grand mosques and Islamic mosques in the Cirebon area. The method of Sunan Gunung Jati's da'wah can be read in traditional Cirebon manuscripts, both conventional da'wah methods through religious lectures and da'wah methods, which are filled with legendary and historical elements.

From here Sunan Gunung Jati is present as a king and guardian who controls parts of West Java whilst at the same time inviting and encouraging the spiritual side of its citizens to embrace Islam. One of the manifestations of Sunan Gunung Jati's solicitation was contained in the form of Sunan Gunung Jati's heritages that were related to religious issues and humanitarian social issues. Martabat tembung wali is known as a teaching that must be followed and applied in life the gugon tuwon (derived from the word gugu, which means 'obeyed' and 'followed', and tuwo, which means parent). It contains advice and teaches about the life and behaviour that humans should live. Martabat tembung wali not only appropriate to the lifetime of Sunan Gunung Jati but still very contextual to the current conditions. These are the facts that are part of the daily philosophy and perspective of the people of Cirebon.

\section{Religious humanism}

The teachings of Sunan Gunung Jati are known as martabat tembung wali which is related to Islam, especially teachings in worship and behavior. Efforts to understand the teaching concept can be done through interpretation of the form and content contained in martabat tembung wali. This interpretation effort can be done by adapting to contemporary problems and using a framework of values that are generally accepted or commonly used, such as values of piety and belief, discipline, wisdom and policy, politeness and manners, and social life. From these common or frequently used values, it can be used as a benchmark for examining the contents of the martabat tembung wali. So that it can be known and classified according to the meaning contained therein. The values of the teachings are interpreted according to the present interpretations as follows:

\section{Teaching values on the personal side}

In the teachings of Sunan Gunung Jati, there are several values that show that the human side can be seen from the perspective of the human person. There are several teaching values that show that human beings are independent beings. The first one is the concept of 'den bisa megeng ing hawa nafsu' [should be able to resist lust]. The unpleasant character is often found in everyday life, such as breaking the law. In the context of 'lusting', what is meant is to practise his skills for deviant actions. This concept emphasises the control of human sensual desires. Control of lust is closely related to emotional control. Robert and Cooper cited by Agustian (2001:44) revealed that emotional intelligence is the ability to feel, understand and effectively apply power and emotional sensitivity as a source of energy, emotion and human influence. The process of controlling emotions is closely related to human self-control through the process of logic and judging good or bad. Through the ability to think well, humans can control their emotions so that there is a balance between their thoughts and actions.

The second is the concept of 'aja nyindra janji mubarang', which means not to break the promise. The third is the concept of 'pemboraban kang ora patut anulungi', which means that the wrong one does not need to be helped. The fourth one is the concept of 'aja ngaji kejayaan kang ala rautah', which means not to study for wrong or misused interests.

\section{Teaching values on the social side}

Martabat tembung wali form 'duwehi sifat dan wanti' it means to have a cautious nature or a cautious nature. Means to have a cautious or cautious nature. The meaning contained in interacting and communicating should be able to display the qualities and attitudes that are generous and compassionate. The nature of caution, compassion will be generous is a personal protector in social life, through a compassionate approach, psychological links can be established well, besides that it can avoid jealousy and conflict between individual interests. Martabat tembung wali of 'aja cok ngijek rarahi ing wong' means do not like to ridicule other people. The meaning contained is far from being insinuating and insulting others. Humiliation that comes out of speech, whether we realize it or not, can hurt someone's heart and the heart that has hurt 
the medicine is only two responses, firstly patience and trust in God and secondly reply back until satisfied. This second aspect can result in mutual hatred and mutual resentment between individuals with each other. Therefore, the second aspect must be avoided wisely. According to Plato, justice is a balance or harmony (Rasuanto 2005:8). Mutual respect is manifested in the form of tolerance and love for each other. Tolerance occurs when everyone wants to understand and accept differences as a multicultural society. Tolerance is a manifestation of the social sense of humanity that recognises differences.

Petatah-petitih 'kenane ing hajate wong' means that someone's wishes are granted. The meaning contained in petatah-petitih is manifesting someone's desire or hajt if he is capable, not harming the person and endangering the general public. Pleasing people is worship (making people because they avoid difficulties) and vice versa makes the persecutor very hated by God prioritising. Therefore, Sunan Gunung Jati reminded the children and their descendants not to be selective in fostering the community to adhere to Islamic values. This concept focuses on a sense of social care. Social care is an attitude of connection with humanity in general, an empathy for every member of the human community (Purwulan 2015:60).

Social care focuses on humanitarian issues caused by the low quality of the social environment. A sense of social care can be transmitted into social assistance to others. Social care is done in terms of various sciences, helping each other in fulfilling primary needs (clothing, shelter and food). As social beings, every human being has a moral and social responsibility towards each other.

\section{Teaching values on the spiritual side}

Martabat tembung wali of 'Ibadah kang tetep' means diligent worship. These exhibits contain the meaning of worshiping with full awareness and patience so that the worship is beneficial for himself and his family. Perform worship quietly as a form of getting closer to God. Widespread worship implies that all activities of human life are guided by and departed from the pleasure of Allah, which has advantages both physically and psychologically. The wisdom of carrying out routine worship is to exercise self-discipline, increase a sense of responsibility, maintain the dignity of religious beliefs and can improve the quality of faith and piety to God. Martabat tembung wali of 'yen sembahyang fungsi pucuke panah' means the prayer is like the tip of an arrow. These meanings contain the meaning of praying with full solemnity as if God saw it and prayed with full sincerity so that the prayer service is useful and gets a high reward. Understanding arrows is a figurative meaning that is worship with full of humility and calm so that between speech, heart and movement has systematic coordination. Prayer can build a patient mental attitude. Martabat tembung wali of ' $k u d u$ ngakehaken pertobat' means lots of repentance. These writings contain the meaning that the human being should be asking for forgiveness in the presence of God for all acts of speech and deed. Repentance is not only in the sense of returning to the right path, but more broadly it is to re-explore the sources of Islamic teachings for the benefit of Muslims and the quality of the faith of every Muslim.

Repentance awareness is the first step for humans to know, acknowledge and explore Islamic teachings comprehensively. Therefore, the need to build awareness and increase motivation to worship is important for a Muslim. This concept refers to activities of self-reflection. Martabat tembung wali of 'wedia ing Allah lan ingsun' means to fear Allah and to himself. These stories contain the meaning of being afraid of God. The real manifestation of fear is being able to abandon all prohibitions and be able to carry out all the rules. Martabat tembung wali of 'wedia ing ingsun' means fear of themselves. The meaning contained is the content or filling of the heart with faith because faith is a protector of behavior. If this can be controlled, then fear of committing sins, shame of doing wrong, ashamed of not worshiping can be controlled, it can increase selfintrospection. This does not mean that he himself must be feared, but actions that contradict the norms that need to be feared, bad character and speech that need to be avoided. Self-reflection is a process of looking back at the process in thoughts and feelings (Anantasari 2012:195). Self-reflection is an activity to look back on what has been done so that whilst acting one becomes more careful. Self-reflection is an activity of thinking, which in various feelings, perceptions, imagination and thoughts give influence in forming a person's behaviour, tendencies, beliefs and good and bad habits.

The Martabat tembung wali presented here are proof of how much Sunan Gunung Jati hoped to teach his children and descendants to always ask for the blessings and guidance of God to live in this prosperous world and hereafter. The above statements about the re-understanding of Sunan Gunung Jati's teachings are related to the value of religious humanism.

The manifestation of actions conveyed in these values refers to the character to advise each other as well as values related to attitudes of belief, discipline, tolerance, politeness and responsibility. The values contained in the MTW expression can be seen in the table below (Table 1).

The teachings of Sunan Gunung Jati contain the majesty of God or piety, which is displayed through ways of behaving humanly, civilised and humble, disciplined behaviour and manners with parents and other people. Therefore, the Martabat tembung wali which contains life value was born, which contained the value of life. Sunan Gunung Jati teaches about the procedure for developing oneself into a virtuous human being. Sunan Gunung Jati prioritises the process of forming self-wisdom through social and spiritual activities. In achieving the full person, humans are taught to always think rationally, work hard and to live with discipline and 
TABLE 1: The values contained in the MTW expression.

\begin{tabular}{|c|c|}
\hline Wejangan & Nilai \\
\hline $\begin{array}{l}\text { yen sembahyang kungsi pucuke panah } \\
\text { yen puasa den kungsi tetaling gundewa } \\
\text { ibadah kang tetep } \\
\text { wedia ing Allah } \\
\text { manah den syukur ing Allah } \\
\text { kudu ngakehaken pertobat }\end{array}$ & Devotion or belief \\
\hline $\begin{array}{l}\text { aja nyindra janji mubarang } \\
\text { pamboraban kang ora patut anulungi } \\
\text { aja ngaji kejayaan kang ala rautah }\end{array}$ & Discipline \\
\hline $\begin{array}{l}\text { singkirna sifat kang den wanci } \\
\text { duweha sifat kang wanti } \\
\text { angadahna ing perpadu } \\
\text { kenana ing hajate wong } \\
\text { aja ngagungaken ing salira }\end{array}$ & Tolerance \\
\hline $\begin{array}{l}\text { den hormat ing wong tua } \\
\text { den hormat ing leluhur } \\
\text { hormaten, emanen, mulyaken ing pusaka } \\
\text { den welas asih ing sapapada } \\
\text { mulyaken ing tetamu }\end{array}$ & Politeness or manners \\
\hline $\begin{array}{l}\text { aja anglakoni lunga haji ing Makkah } \\
\text { aja munggah gunung gede utawa manjing kawah } \\
\text { aja ngimami atau khotbah ing masjid Agung } \\
\text { aja dagangan utawa warungan } \\
\text { aja lunga layaran ing lautan }\end{array}$ & Responsible \\
\hline
\end{tabular}

Tembang Carang Status Sejarah Ampel Rembesing Madu Pastika Padane

responsibility. Whilst making personal contact with fellow human beings, one should put forward the principle of tolerance. The main goal is to achieve a harmonious life and have a caring attitude amongst others. The process of personal and social self-development is carried out together with the spiritual aspects to achieve self-glory by constantly reflecting.

\section{Conclusion}

Based on the explanation above, history has a very broad understanding. In understanding history requires a stage to find a value that becomes wisdom for the people. The teaching of Sunan Gunung Jati has a concept with religious humanism as a form of history. Religious humanism is a religious perspective that places mankind as a human being and a humanisation of the sciences with full faith accompanied by human relations with God and fellow human beings. When associated with the world of education, religious humanism is an educational concept that refers to the existence of 'humanising human beings' to develop all abilities possessed by humans intellectually and religiously without abandoning the underlying religious values. In the history of Sunan Gunung Jati, the legacy of philosophical teachings is the result of acculturation of understanding of mind, culture and religion. Sunan Gunung Jati's heroes are one of the legacies of local wisdom that is able to provide positive social and spiritual influences. Sunan Gunung Jati's heroes were adapted from the holy verses of the Koran, which were revealed using more textual language according to the social and cultural conditions of the community. The contents of Sunan Gunung Jati's stories can be valid throughout the ages, and not only for the lifetime of Sunan Gunung Jati because their teachings have relevance to the present. History is not only a relic but history has values that can be implicated in life. This philosophical teaching in martabat tembung wali signifies a wisdom in local history, whilst history has wisdom that can be used as a reference in living the present life.

\section{Acknowledgements}

The authors would like to thank all of those who contributed to this article: resource persons from the Kasepuhan Palace in Cirebon who have information related to this research.

\section{Competing interests}

The authors declare that they have no financial or personal relationships which may have inappropriately influenced them in writing this article.

\section{Authors' contributions}

L.E.P. and S.S. together compiled this article.

\section{Ethical consideration}

Ethical clearance to conduct the study was obtained from Sebelas Maret University (clearance number: 3805/UN27.02/ DP/2019).

\section{Funding information}

This research received no specific grant from any funding agency in the public, commercial or not-for-profit sectors. It was self-financed.

\section{Data availability statement}

Data sharing is not applicable to this article as no new data were created or analysed in this study.

\section{Disclaimer}

The views and opinions expressed in this article are those of the authors and do not necessarily reflect the official policy or position of any affiliated agency of the authors.

\section{References}

Abidin, Z., 2011, Filsafat Manusia, Rosda Karya, Bandung.

Agustian, A.G., 2001, Rahasia Sukses Membangun Kecerdasan Emosi dan Spiritual (ESQ) Jilid Pertama, Arga Wijaya Persada, Jakarta.

Anantasari, M.L., 2012, 'Model Refleksi Graham Gibbs untuk Mengembangkan Religiusitas', Teologi 01(02), 195. https://doi.org/10.24071/jt.v1i2.430

Carr, E.H., 2014, Apa Itu Sejarah, Komunitas Bambu, Jakarta.

Endar, H., 2008, Humanisme dan Agama dalam Humanisme dan Humaniora Relevansinya Bagi Pendidikan ed. Bambang Sugiharto, Jala Sutra, Yogyakarta.

Fajarini, U., 2014, 'Peranan Kearifan Lokal dalam Pendidikan Karakter', Sosio Didaktika 1(2), 123-130. https://doi.org/10.15408/sd.v1i2.1225

Isna, M., 2001, Diskursus Pendidikan Islam, Global Pustaka Utama, Yogyakarta.

Mas'ud, A., 2003, Menuju Paradigma Islam Humanis, Gama Media, Yogyakarta.

Miles, M.B. \& Huberman, A.M., 2007, Analisis Data Kualitatif: Buku Sumber Tentang Metode-metode Baru, UI Press, Jakarta.

Moleong, L.J., 2007, Metodologi Penelitian Kualitatif, Remaja Rosda Karya, Bandung. Nurkholis, 2010, 'Reorientasi dan Implementasi Pendidikan Humanis Religius', Taalum 20(01), 8.

Purwulan, H., 2015, 'Kepedulian Sosial dalam Pengembangan Interpersonal Pendidik', Ilmiah Pendidikan 03(01), 59-65.

Rasuanto, B., 2005, Keadilan Sosial: Pandangan Deontologis Rawsl dan Habermas, Dua Teori Filsafat Politik Modern, Gramedia, Jakarta.

Sutopo, H., 2006, Metode Penelitian Kualitatif, UNS Press, Surakarta.

Wijaya, D.N., 2015, 'R.G. Collingwood dalam Idealisme Historis', Sejarah dan Budaya 9(1), 14. https://doi.org/10.17977/sb.v9i1.4784 